\title{
The Language Awareness of Finnish and German EFL Senior High School Learners and Student Teachers Regarding English Grammar and Its Teaching
}

\author{
Esa M. Penttinen ${ }^{1, *}$, Heiner Böttger ${ }^{2} \&$ Jens Behning ${ }^{3}$ \\ ${ }^{1}$ University of Helsinki, Finland \\ ${ }^{2}$ Catholic University of Eichstaett-Ingolstadt, Germany \\ ${ }^{3}$ Ludwig Maximilian University of Munich, Germany \\ *Correspondence: Faculty of Behavioral Sciences, Department of Teacher Education, Foreign Language Education, \\ University of Helsinki, P.O. Box 9, Siltavuorenpenger 5 A, FI-00014, Finland. Tel: 358-50-448-2411. E-mail: \\ esa.penttinen@helsinki.fi
}

Received: March 24, 2019

Accepted: May 29, 2019 Online Published: June 25, 2019

doi:10.5430/ijelt.v6n2p1

URL: https://doi.org/10.5430/ijelt.v6n2p1

\begin{abstract}
The aim of this study is to examine and contrast the language awareness of Finnish and German EFL senior high school students and student teachers regarding aspects of English grammar and its teaching. Data was collected from Finland and Germany during the academic school years of 2015-16 and 2016-17. It consists of the responses to two survey questions of 1st year EFL senior high school students $(n=200$ from Finland, $n=200$ from Germany) and student teachers ( $\mathrm{n}=118$ from Finland, $\mathrm{n}=118$ from Germany). The study utilizes both qualitative (content analysis) and quantitative (frequencies, percentages, cross tabulation [ $\chi 2$-test]) research methods. The results show that the subjects' awareness of English grammar and its teaching was mainly based on intuitive, implicit knowledge. It was difficult for both senior high school learners and student teachers to build a cognitive understanding that would increase their awareness of English grammar, and, as a result of this, its teaching, and respectively their grammar-related didactical competences.
\end{abstract}

Keywords: language awareness, grammatical awareness/knowledge, explicit, intuitive, unclear awareness

\section{Introduction}

The aim of the present paper is to examine and contrast the language awareness of Finnish and German EFL senior high school students and student teachers regarding aspects of English grammar and its teaching. It is a follow-up study to a previous Finnish and German awareness-raising research project by Penttinen and Behning (2017). We collected the material for this study from the responses to two questions. These were for both groups the same, the first one related to a linguistic problem solving and the second one to the teaching of the English grammar. We presented the questions to first-year students from five Finnish-language senior high schools and from three German senior high schools and to student teachers from the University of Helsinki, Ludwig Maximilian University of Munich, and the Catholic University of Eichstätt-Ingolstadt. The Finnish and the German senior high school students had studied English as their first foreign language since the third grade of elementary school. The instruction of English they received was based on the curriculum for the senior high schools: in Finland on the National Core Curriculum for General Upper Secondary Schools (FNBE, 2015), in the German School of Helsinki on Lehrplan für den Erwerb der allgemeinen Hochschulreife (TMBJS, 2011), and in Bavaria on Lehrplan für das Gymnasium in Bayern (ISB, 2004). The content and goals of the curricula of Finland, Thuringia, and Bavaria are consistent with the Common European Framework of Reference for Languages (CEF, 2001). Its main aim is to provide a common basis for the elaboration of a language syllabus, curriculum guidelines, examinations, textbooks, and so on, that is to say, a method of learning, teaching and assessing, which applies to all languages in Europe.

Language, grammar, and language awareness are concepts that are difficult to adopt. Aaltonen (2009, p. 16) defines 
language as a system of symbols and rules. Karlsson (2000, pp. 22-23) on the other hand considers grammar as having the dual role of being both structural and prescriptive: grammar is, on the one hand, the structural system of a language and, on the other hand, the system regulating the language use of a single individual. The norms associated with grammar become a tool for evaluating the accepted manner of transmitting meaning in a given language.

In Finnish literature, the concepts of awareness and language awareness are often used in a confusing and misleading way. According to the Kotimaisten kieltenkeskus (2017), awareness means (i) being aware; knowledge and (ii) consciousness. The Association for Language Awareness (http://www.languageawareness.org/?page_id=48) defines "Language Awareness as explicit knowledge about language, and conscious perception and sensitivity in language learning, language teaching, and language use." Awareness and attentiveness are closely linked, but they cannot be considered synonyms for each another. According to Koivisto (2006, p. 287), some matters are chosen to be more thoroughly processed, and others are left out of the process. Knapp (2010) puts it similarly when he differentiates between Sprachbewusstheit (linguistic/language awareness) and Sprachaufmerksamkeit (language awareness, i.e., learning intent, learning attention, understanding of the substance, overview of speech performance), emphasizing that the attentiveness is a preconditional ability to focus on the form of language. In other words, attentiveness is a choice, whereas phenomenological consciousness depends on subjective experience.

\section{Language Awareness and Its Teaching}

In our own research context, we discuss language awareness along the same lines as (i) Andrews (1999), (ii) Dufva (2000) and (iii) Luchtenberg (2014). According to Andrews (1999, p. 163) the term 'metalinguistic' reflects the qualitative differences between the language awareness/knowledge of the educated user of a language and that required by the teacher of that language. In order to be an effective communicator in the spoken and written media, the language user needs to draw on both explicit and implicit language knowledge. Dufva (2000), for her part, discusses metalinguistic awareness (intuitive/implicit knowledge, an 'intuitive feel' for a language), which facilitates conscious examination of the characteristics associated with both the form and meaning of language. Furthermore, according to Luchtenberg (2014, p. 110), metalinguistic communication consists not only of knowledge about grammar and linguistic terminology but also, in a broader holistic sense, of the ability to verbally communicate about language phenomena involving cognitive, social and emotional aspects. We examine metalinguistic knowledge from the point of view of grammatical knowledge (grammatical competence) and its teaching. According to Dufva (2000, p. 88), school students should be provided with the skills for meta-language thinking and the ability to understand teaching, but teachers themselves must understand what or how they teach. The central task of teaching is to speak of or about (to negotiate) a language, and this it is more central than teaching a language. Our approach is supported by the method used by James $(1998$, p. 260, 1999) to define awareness by regarding the concepts of language awareness, LA, that is, an ability to analyze explicitly one's own mother tongue or an acquired foreign language, and as consciousness raising, $\mathrm{CA}$, as the cognitive ability to speak 'out' the corresponding explicit and implicit parallels between the two languages involved. According to James (1999, p. 104), a teacher may use the knowledge of the students' native language while increasing their awareness of the foreign language being studied. This can be realized only if the native language and the foreign language are studied side by side, 'MT [mother tongue] and FL [foreign language] in tandem,' as James (1999, p. 104) expressed it.

Language learners may have language awareness without being able to explain how they constructed a linguistic expression. According to Polayi (1966, pp. 4-5), 'we can know more than we can tell.' Polayi calls this implicit knowledge tacit knowledge: 'So most of this knowledge cannot be put into words.' In other words, we are unable to say how we know that (in our research, intuitive knowledge), as opposed to explicit knowledge (formal, systematic and well-defined). According to Krashen (1994, pp. 45-46), explicit knowledge is the result of conscious study and implicit knowledge is a subconscious process and it requires a social context (for communication). Nicholas (1991) observed the same phenomenon while he examined the development of linguistic awareness in a child and the contribution of the social environment to it. Andrews (2001) has constructed a concrete 'tool' to facilitate language instruction. He has compared the concept of language awareness to the concepts of pedagogical content knowledge and communicative language skills. According to the concept analysis of Andrews, these three concepts are not identical in content. The language awareness/knowledge of a person is composed of a strategic component, a language component, and a subject component. According to Andrews (2001), the strategic component and the language component are part of the communicative language skills of a person. Therefore, communicative language skills correspond to the definition by Bachman (1991, p. 682), in which language is used for creating and interpreting meanings in various contexts in conformance with social and pragmatic norms. The third component, the subject knowledge of Andrews, that is, 
knowledge of the form and meaning of a language (i.e. grammar, phonology, and vocabulary), which is, on the other hand, the core of pedagogical content knowledge, according to Shulman (1986). The approach of Andrews to language awareness emphasizes dynamism among the various components of a person's language awareness and the view that language awareness is a bridge connecting communicative language skills and pedagogical content knowledge.

During a teaching session, form and content of language are discussed through social interaction. In discussion, the teacher and the students share their understanding of linguistic input and thus may be able to bridge the gap between individual interpretation and socially shared interpretation (Donato, 2000.) According to Halliday (1985, p. xxxv), language is difficult to understand as a system without grammar.

Helmstad (1999, pp. 134-161) defines understanding as (i) reception, (ii) acquisition, and (iii) comprehension of knowledge. According to him, understanding is often seen as the passive reception of knowledge where knowledge is the result of personal observation or of another person transmitting it. On the contrary, acquisition of knowledge requires active endeavor, independently or directed by others. Helmstad sees the comprehension of knowledge in three dimensions: as (i) factual understanding, (ii) referential understanding, and (iii) systemic understanding, and thus the learner comprehends. Helmstad's view of comprehension is consistent with the view on learning to learn presented by Hautamäki et al., (2000, p. 17). According to them, learning to learn requires knowledge, skills, and studying.

\section{Method}

Our study utilizes both qualitative (content analysis) and quantitative (frequencies, percentages, cross tabulation [ $\chi 2$-test] $)$ research methods. Our own study is, according to definitions devised by Syrjälä (1994, p. 13), a limited whole, survey-study. We aim here at paying attention to recognizing new findings and to realizing views based on previous studies. Our approach is consistent with the view of Denz and Lincoln $(2005$, p. 5) on the socially constructed nature of reality and on a close relationship between researchers and the focus of research.

\subsection{Participants and Data Collection}

We chose grammatical knowledge and its related teaching to be the focus of our research. Based on our theoretical framework, we created two questions for gathering the research material, which was collected during the academic school years of 2015-16 and 2016-17 from (i) five Finnish language senior high schools ( $\mathrm{n}=200)$, (ii) three German senior high schools, namely the German School of Helsinki $(n=28)$ and two senior high schools in Bavaria $(n=172)$, (iii) the University of Helsinki ( $\mathrm{n}=118$ ), (iv) two German universities, Ludwig Maximilian University of Munich ( $\mathrm{n}=$ 73) and the Catholic University of Eichstätt-Ingolstadt $(n=45)$. The senior high school students were of the same age, the same grade, and had been learning EFL for the same length of time.

The questions were presented to 215 Finnish and 220 German senior high school students. Four of the Finnish students only answered one question and another eleven answers were too unclear to be analyzed. The corresponding figures for the Bavarian senior high school students were $(n=9)$ and $(n=11)$. All the responses from the students of the German School of Helsinki were included in the study. The same questions were put to 120 Finnish and 122 German teacher students. One of the Finnish teacher students only answered one question and another answer was unclear. All the responses from the teacher students from the Catholic University of Eichstätt-Ingolstadt were included in the study. Two of the teacher students from Ludwig Maximilian University only answered one question and two unclear answers could not be analyzed.

Using problem solving tasks can be considered one form of teaching explicit knowledge of grammar (Stern, 1992, p. 327). The first question we presented to the senior high school students and student teachers pertains to linguistic problem solving. By asking a specific question, we examined their knowledge of grammar. The first question to be answered was the following: Which one of the sentences below was produced by a native speaker? Justify your answer.

A. Before Louis finishes work, he will give us a call.

B. Before Louis will finish work, he will give us a call.

Odlin (1994) used the same sentences when he explored the difference between grammatical rules and the idea contained in them. The second question helped us examine the knowledge of the participants about teaching grammar: How should the problematics associated with the sample sentences be dealt with in English language instruction?

\subsection{Data Procedures}

We evaluated the responses from the senior high school students and the student teachers to the first question with reference to an English grammar book for schools (Mattila \& Mattila, 1984, p. 109). Dirven (1990, p. 1) divides grammar into pedagogical and descriptive grammar. He places the grammar taught in schools close to descriptive 
grammar. It can be evaluated based on how well it describes the form and meaning systems of a language. The responses of the senior high school students and the student teachers were divided into three categories based on how they corresponded to the expression of a future event or activity when a sentence consists of a main clause and a temporal subordinate clause, according to the English grammar book. To the second question we evaluated the responses with the researches by Andrews (1999), Helmstad (1999), James (1998, 1999), Donato (2000), (Dufva (2000) and Luchtenberg (2014) from the point of view of understanding, metalinguistic knowledge of grammatical awareness/knowledge and its teaching. The responses to the second question of the senior high school students and the student teachers were also divided into three categories. We named the categories on the basis of a qualitative and quantitative analysis: explicit, intuitive, and unclear awareness.

Explicit knowledge is usually presented as directives in books, and it is knowledge based on rules (Nevala, 2014). Intuition is subconscious knowledge based on experience, which contributes to coping in daily life (Polayi, 1966, p. 4; Spinney, 1999). It corresponds to intuitive knowledge, in other words, the ability to use a language without thinking about grammatical rules (Dufva, 2000). Suomi Sanakirja (2017), a Finnish dictionary, provides the following synonyms for the word unclear: ambiguous, inexact, illogical.

\subsection{Statistical Analysis}

In addition to the qualitative characteristics of the responses, we wanted to obtain exact information on whether there is an actual difference between the responses of Finnish and German senior high school students and the student teachers, and whether any difference is coincidental. We studied this by calculating the frequencies of responses in the different categories (numerical knowledge) and the percentages (averages). Cross tabulation was the simplest way to find a connection between the two variables (e.g. Finnish senior high school students versus German senior high school students). In order to obtain information about real differences between the groups we performed a Chi-square $\left(\chi^{2}\right)$ Test on the basis of cross tabulation. Results are usually reported on three significance levels: $p<0,001$ (very) significant, $p<0,01$ significant and $p<0,05$ (almost) significant (Metsämuuronen, 2003, pp. 279-298).

\subsection{Research Questions}

Our research questions were as follows:

1. What kind of knowledge related to the English grammar do Finnish and German EFL senior high school students and student teachers have?

2. What kind of knowledge related to the teaching of English grammar do Finnish and German EFL senior high school students and student teachers have?

\section{Results}

Next, we will answer the research questions posed in the previous chapter. The first one was related to a linguistic problem solving and the second one to the teaching of the English grammar.

\subsection{Knowledge of English Grammar}

We will answer the first research question by analyzing the responses of the EFL senior high school students and student teachers to the question related to the knowledge of English grammar. According to James (1998, p. 65), the correctness of language is not determined by the language user but by an outside party who, according to him, is someone other than you or me. In a classroom situation, the teacher has the role of the outside party who evaluates the grammatical correctness of the language produced by a student, based on the grammar taught in a given school. In our study, we took the role of the teacher. We examined the quality and quantity of the language knowledge of the EFL senior high school students and the student teachers, how they organized their language knowledge into their own knowledge structures and how they were able to utilize it. In this article, we examine more closely the responses of a few study participants to the first and second questions. Thus, we will acquire information regarding the grammar knowledge and the factors contributing to their language awareness, in other words, regarding the effectiveness of teaching. Table 1 illustrates how the responses of the senior high school students and the student teachers were distributed. 
Table 1. Distribution of the Responses by the Senior High School Students and the Student Teachers into Awareness Categories Regarding the First Question

\begin{tabular}{llll}
\hline Respondent group & Explicit & Intuitive & Unclear \\
\hline Finnish Senior High School Students $\mathrm{n}=200$ & $(\mathrm{n}=45) 23 \%$ & $(\mathrm{n}=91) 46 \%$ & $(\mathrm{n}=64) 31 \%$ \\
German Senior High School Students $\mathrm{n}=200$ & $(\mathrm{n}=12) 6 \%$ & $(\mathrm{n}=96) 48 \%$ & $(\mathrm{n}=92) 46 \%$ \\
Finnish Student Teachers $\mathrm{n}=118$ & $(\mathrm{n}=31) 26 \%$ & $(\mathrm{n}=57) 48 \%$ & $(\mathrm{n}=30) 26 \%$ \\
German Student Teachers $\mathrm{n}=118$ & $(\mathrm{n}=10) 8 \%$ & $(\mathrm{n}=41) 35 \%$ & $(\mathrm{n}=67) 57 \%$ \\
\hline
\end{tabular}

The responses of the senior high school students and student teachers to the first question included the following expressions: Explicit category: future tense in the main clause, present tense in the subordinate clause, no two future tenses, future tense is not to be repeated, the main clause has future tense, subordinate clause has the present tense. Intuitive category: A sounds better, more correct, more fluent. Unclear category: I don't know, native speakers use contractions in language, do not follow rules of grammar, can use either in subordinate clauses.

In the following, we will take a closer look at the responses in the different awareness categories. We will use the following abbreviations: no. $=$ number, $\mathrm{f}=$ female, $\mathrm{m}=$ male, $\mathrm{FH}=$ Finnish senior high school student, $\mathrm{GH}=\mathrm{German}$ senior high school student, FS = Finnish student teacher, GS = German student teacher.

Examples (1-7) illustrate the explicit responses of the participants in our study to the first of our questions:

(1) A, because it is grammatically correct. Finns also often speak their own language grammatically incorrectly, so the answer could also be B. However, the B-option repeats the word will unnecessarily, which makes the sentence more cumbersome. A-response can also be heard more for instance in TV-programs, so it should be said pretty automatically. (no. 67, f, FH)

(2) Sentence A was produced by the native speaker, because B used will-future twice - also grammatically wrong. (no. 226, $\mathrm{m}, \mathrm{GH}$ )

(3) A sentence is spoken by a native speaker, because B has an unnecessary auxiliary verb in a subordinate clause. A mere present tense is enough. (no. 407, m, FS)

(4) A. Native speakers know that if a sentence includes a word referring to time, before-clause must not include the word will. (no. 425, f, FS)

(5) Although the word will is used in English to construct the future tense, it is not used in sentences that begin with the word before, rather than the present tense of the verb is used. (no. 465, m, FS)

(6) Sentence A is produced by a native English speaker. 'Will' is not used twice in English grammar, in A the tempi of the verb are used correctly. (no. 543, f, GS)

(7) A: Rule - no will-future in sentences with 'before'. (no. 569, f, GS)

The Finnish senior high school student's response (1) conforms to the learning process model of Gass and Selinker (2001, pp. 410-412), which includes the following segments: the meaningful input in the learner's mind, input comprehended by the learner, intake internalized by the learner, the integration of the learned material, and output.

A portion of the students of the German senior high school students considered their knowledge of the English grammar from the point of view of their mother tongue. This may be due to the German language being typologically closer to the English language than it is to Finnish. The following example (8) from our material shows more clearly the explicit response of a German senior high school student to the first question:

(8) For me, the first sentence sounds much better than the second, like from a native speaker and it is grammatically correct. In German you do not say yes 'Bevor Louis seine Arbeit zu Ende bringen wird, wird er uns anrufen.' ['Before Louis will finish work, he will give us a call.'], but 'Bevor Louis seine Arbeit zu Ende bringt, wird er uns anrufen.' ['Before Louis finishes work, he will give us a call.'] (no. 381, f, GH)

In their study, Verspoor and Behrens (2011, pp. 27-28, 30) have dealt with the significance of the mother tongue in learning a foreign language with the help of the concepts similarity and difference. According to them, a language learner finds it easier to adopt languages that have a lot of similarities to their own mother tongue. It also means that speakers of different languages have different difficulties learning the same foreign language. 
For their part, the intuitive responses (9-13) of the senior high school students and teacher students reveal that they are aware, on the basis of their intuitive language awareness, of the linguistic problematics of the first question, but they cannot articulate their thoughts in words, a matter which, among others, Polayi (1966) and Nicholas (1991) have examined in their studies, or they have not internalized the given grammatical issue, 'How something works', as Helmstad (1999, pp. 153-155) expressed it.

(9) The second option has a double future tense, which sounds weird in English. (no. 66, m, FH)

(10) A sounds better. B sounds a bit wrong, so many times 'will'. (no. 224, f, GH)

(11) A, because it sounds more correct. I don't know the logic of it, but mostly languages like simpler forms. (no. 412, $\mathrm{m}, \mathrm{FS}$ )

(12) I think A was produced by a native speaker because it sounds better. It sounds more natural and makes more sense, because otherwise there is 'will' in the sentence twice, and that does not work correctly in any grammatical sense. (no. 534, f, GS)

(13) Sentence A, because it sounds more diligent and is easier to pronounce than sentence B. (no. 537, f, GS)

We next provide four examples of unclear responses (14-17) to our first question by the Finnish and German participants:

(14) B, because in English classes we are taught the structure as in A sentence, but B is the way of expressing a matter for someone speaking in their mother tongue. (no. 8, m, FH)

(15) A. Because I think that native speakers do not pay attention to grammar for they don't care how they use it. Only the content of the sentence is important to them. (no. $343, \mathrm{~m}, \mathrm{GH}$ )

(16) A, native speakers drop as many extra words and sounds from their language as possible. (no. 401, m, FS)

(17) B. Even if the grammar is correct in A, sentence B sounds more natural, so I think it was produced by a native speaker in an everyday situation. (no. $629, \mathrm{f}, \mathrm{GS}$ )

The responses reveal that many of the senior high school students and student teachers have not recognized the set goal of the gap or of the alignment of language awareness and their own language awareness, which, according to James (1998, p. 260), is a prerequisite for increasing language awareness. Alternatively, they have not understood what they do not know, and what they should still learn in order to reach the said goal (Helmstad, 1999, pp. 134-161). According to the FNBE (2015, pp. 114-115), the general objectives of the teaching and learning in the different syllabi in foreign languages is that the students are able to evaluate their competence and to plan their language studies for their future needs from the perspectives of further studies, working life, and internationalization. Unclear responses also point to the inadequate subject knowledge of the respondents. Andrews' subject knowledge (2001), that is, knowledge of the form and meaning of a language (i.e. grammar, phonology, and vocabulary) is, on the other hand, the core of pedagogical content knowledge, according to Shulman (1986). Unclear responses also indicate that the high school students and student teachers had difficulties comprehending language as a grammatical system (cf. Halliday, 1985, p. xxxv; Helmstad, 1999, pp. 134-161).

The statistical analysis showed that, regarding the first question, there was a significant difference $(\chi 2(2)=46,879 ; p=$ $0,000)$ between the responses of the Finnish and German senior high school students and student teachers such that the Finns appear to be more knowledgeable about the tested grammar phenomenon than the Germans. Upon closer examination of the responses given by the Finnish and the German senior high school students to the first question, it appears that there was also a significant difference between the responses of the senior high school students $(\chi 2(2)=$ $24,265 ; p=0,000)$. The Finnish senior high school students would seem to be more knowledgeable about grammar than their German counterparts. There was likewise a significant difference $(\chi 2(2)=27,482 ; p=0,000)$ between the responses given by the Finnish and the German teacher students to the first question in favor of the Finnish teacher students. No statistically significant difference exists between the genders of the senior high school students and student teachers regarding their responses to the first question.

\subsection{Knowledge of English Grammar Teaching}

Regarding the second question in our study, we examine the depth of pedagogical knowledge of our study subjects about grammar. We answer this question by analyzing the responses of our study participants to our question about how the problematics involved in the sample sentences should be dealt with in English language instruction.

In our analysis, we have considered the fact that senior high school students are not necessarily able to articulate how issues relating to learning grammar should be examined in language instruction. They can, nevertheless, explain how 
they have been taught or should be taught. A portion of the knowledge heard and read by them is filtered into such knowledge that their selective attentiveness attaches to, as Koivisto (2006) has characterized the process. The responses of those involved in the study bring out their awareness of the form and meaning of the language and their understanding of how these issues have been spoken about or should be in an English lesson. Table 2 illustrates the distribution of the responses given by the senior high school students and by the student teachers to the second question.

Table 2. Distribution of Responses by the Senior High School Students and Student Teachers into Awareness Categories Regarding the Second Question

\begin{tabular}{llll}
\hline Respondent group & Explicit & Intuitive & Unclear \\
\hline Finnish Senior High School Students $\mathrm{n}=200$ & $(\mathrm{n}=67) 34 \%$ & $(\mathrm{n}=74) 37 \%$ & $(\mathrm{n}=59) 29 \%$ \\
German Senior High School Students $\mathrm{n}=200$ & $(\mathrm{n}=48) 24 \%$ & $(\mathrm{n}=91) 46 \%$ & $(\mathrm{n}=61) 30 \%$ \\
Finnish Student Teachers $\mathrm{n}=118$ & $(\mathrm{n}=26) 22 \%$ & $(\mathrm{n}=50) 42 \%$ & $(\mathrm{n}=42) 36 \%$ \\
German Student Teachers $\mathrm{n}=118$ & $(\mathrm{n}=32) 27 \%$ & $(\mathrm{n}=46) 39 \%$ & $(\mathrm{n}=40) 34 \%$ \\
\hline
\end{tabular}

The responses of the senior high school students and student teachers to our second question included the following expressions: Explicit category: grammar with the help of examples, corresponding exercises, discussions about rules of grammar, clear rules, negotiating/talking about rules. Intuitive category: not specifically taught, you just learn, teacher speaks good English, you learn on the fly, with the help of conversation/music. Unclear category: one form is taught, another one is not, I don't know, no point in delving into, no idea, hard to teach, avoiding repetition, the teacher must be naive, mistakes gradually disappear.

In the following section, we will take a closer look at the responses in the different awareness categories. Examples (18-21) exemplify the explicit responses of the study participants to the second question:

(18) Myself I learned the logic in this with the help of a 'diagram' shown by the teacher, which soon makes sense when you understand its similarity to what you've heard previously. This only works if you are susceptible enough to such a structure, so that you grasp the idea when you see a diagram or a graph. Teaching should expose students to correct grammar. (no. 67, f, FH)

(19) Illustrate with books or have the teacher explain it. (no. 226, m, GH)

(20) Students should be taught that what happens in the future is not always described in the same manner - not in Finnish, either. (no. 465, m, FS)

(21) - introduce with the help of example sentences - find rules.

- then do exercises for consolidation (no. 569, f, GS)

The response (18) by a Finnish senior high school student especially supports the ideas of Gass and Selinker (2001, pp. 400-401) on how students themselves determine the actual limits to input directed at them. If a student manages to integrate new information with previous experiences, it is possible for the knowledge spurring the learning process to become classified. Previous experience not only means cognitive language skills, but also refers to an affective acceptance of deeming the act of learning to be necessary.

The explicit responses $(22,23)$ of Finnish and German student teachers reveal how comprehension of language requires directing a student towards a conceptual change.

(22) Grammatical tenses ought to be discussed and it should be made clear that tenses in the Finnish language cannot always be applied to translations. Modal auxiliary verbs should also be talked about and discuss their gradations and effect on the meaning of a sentence. (no. 407, m, FS)

(23) Tense by tense should be explained, and case by case, and also grammar rules should be discussed. (no. 543 , f, GS)

In a teaching situation, the students and the teacher discuss the form and substance of language in social interaction (Donato, 2000; Dufva, 2000). The issue is complicated by the fact that the relationship between form and meaning is not one-to-one when transitioning from one language to another (Tomlin, 1994, p. 145, p. 151). The senior high school students also paid attention to this issue in the examples $(22,23)$ above. James $(1998$, p. 260) uses the expression consciousness raising, by which he means the ability of a teacher to explicate parallels of explicit and implicit language. In his research, Luchtenberg (2014, p. 110) uses the expression metalinguistic communication not only relating to the 
knowledge of grammar and linguistic terminology but also in a broader holistic sense. According to James (1999), in spoken language, comprehension of meaning in the native language is a crucial part of the learning process.

We had placed the responses $(24,25,26)$ of one Finnish and one German senior high school student as well as of one Finnish student teacher to the first question in the intuitive awareness category. We had also placed their responses to the second question in the same category.

(24) It would be helpful to listen to English from interesting sources, so that the correct sample sentences would stick to your mind. (no. $66, \mathrm{~m}, \mathrm{FH}$ )

(25) Watch more English movies / read books. (no. 224, f, GH)

(26) Not in particular. Many forms can be understood. Enough input and output and mistakes would probably disappear by and by. (no. 412, m, FS)

The responses of the participants did not always adhere to one language awareness category or to its matching pedagogical subcategory, and they could also vary even with one respondent. This is exemplified by a German senior high school student, whose first response was placed in the explicit knowledge category, whereas the response (27) to the second question was placed in the unclear knowledge category.

(27) To be honest, I have no idea how to teach this to other nutcrackers like us. (no. 381, f, GH)

This student had explicit awareness of grammar but unclear awareness of the teaching of grammar, that is, how grammar has been or should be taught. The following example also illustrates how the responses of one student teacher could be distributed into different subcategories. We placed the first response of a Finnish student teacher in the explicit awareness category, but the second response (28) in the intuitive awareness category:

(28) Reading a lot of sample sentences and listening to tips on tape. It is demanding to produce language, so it would be good to read sentences aloud. (no. $425, \mathrm{f}, \mathrm{FS}$ )

This student teacher considered learning a language to be memorizing and as rather arduous work, as had been expressed by a German language teacher in an earlier study by Penttinen (2005, p. 104), 'The German language requires much practice and systematic work'. On the other hand, we placed the responses given by a German student teacher to the first and to the second question in the intuitive awareness category. The response (29) to the second question could also have been placed in the explicit awareness category, because the student recommends a concrete 'tool' (see Andrews, 2001), which would help the teaching of grammar by using songs:

(29) I could often avoid typical mistakes by remembering songs or sayings. So, if you make a rhyme out of it. Like for example 'he, she, it das s muss mit.' (no. 534, f, GS)

Here is another example (30) in the intuitive awareness category, a response by a German student teacher.

(30) That it also means in German: 'Sobald Louis die Arbeit beendet hat, wird er uns anrufen.' and more rarely: 'Sobald Louis die Arbeit beendet haben wird, wird er uns anrufen.' Both are correct, but the second one is also more complicated. (no. 537, f, GS)

The response of this student teacher is complex. We could just as well have placed the said example, according to James (1999, p. 104), in the explicit, and also in the unclear awareness category. A teacher may utilize the students' knowledge of their native language while increasing their awareness of the foreign language when parallels can be drawn between the two languages. The CEF (2001, pp. 4-5) represents the same plurilingual view, according to which a person does not learn a foreign language in separation from the previous language system constructed around the native language.

We had placed the responses $(14,15)$ of the senior high school students and the responses $(16,17)$ of the student teachers to the first question in the unclear awareness category. Their responses (31-34) to the second question were also placed in the unclear awareness category:

(31) As mentioned above, version B is taught, and the other option is sort of overshadowed. (no. 8, m, FH)

(32) I believe that this issue should not be dealt with in English lessons, because those who are native speakers will make such mistakes, for they don't worry about them, like German native speakers speaking their language. (no. $343, \mathrm{~m}, \mathrm{GH})$

(33) Producing language idiomatically. Sometimes language departs from the grammatically correct usage. This is hard to teach, it just has to be accepted. (no. 401, m, FS) 
(34) The correct grammar should be taught in any case, pointing out that there are local differences (especially in English in different countries), and that native speakers do not always express themselves correctly. (no. 629, f, GS)

According to the CEF (2001, p. 113), grammatical competence refers to the ability to understand and express meaning by recognizing and producing well-formulated expressions and sentences, as opposed to reciting them from memory. High school students found it difficult to explain how they had been taught or should have been taught, and student teachers found it difficult to teach grammar. In other words, they found it hard to find a pedagogical approach to knowledge that they either do not comprehend or have not internalized, an issue that Andrews (2001), Bachman (1991), Shulman (1986) and others have examined in their studies.

We also sorted out the differences among the responses to the second question with the help of a more exact statistical analysis. We used the same statistical methods that we had used for the first question. The statistical analysis showed that there was no statistically significant difference between responses to the second question by the Finnish and the German senior high school students $\left(\chi_{2}(2)=4,924 ; p=0,085\right)$, and nor was there one between the Finnish and the German student teachers $(\chi 2(2)=0,836 ; p=0,658)$. No statistically significant difference existed between responses to the second question of the high school students and student teachers and their gender.

\section{Conclusions}

The aim of this study was to examine and contrast the language awareness of Finnish and German EFL senior high school students and student teachers regarding aspects of English grammar and its teaching. The study comprised students from five Finnish senior high schools, from the German School of Helsinki, and from two senior high schools in the state of Bavaria, and student teachers from the University of Helsinki, Ludwig-Maximilian University and the Catholic University of Eichstätt-Ingolstadt. The first question in our survey involved solving a linguistic problem. We thereby evaluated the awareness of English grammar of the study participants. The second question involved the teaching of grammar, and we examined how senior high school students and student teachers could increase their own awareness of grammar or how student teachers could increase that of their school students through instruction. The responses of the participants were distributed in three categories for each question. We named the categories based on the qualitative and quantitative analysis as follows: explicit, intuitive, and unclear awareness.

The statistical analysis showed a significant difference $(\chi 2(4)=186,074 ; p=0,000)$ between the responses given by the senior high school students and the student teachers to both questions. In other words, those who had responded with awareness to the first question also responded with awareness to the second question. Correspondingly, those who gave an unclear answer to the first question also gave an unclear answer to the second question. We here provide further examples of linguistically aware responses to both of our questions, made by a Finnish senior high school student:

(35) A, because it sounds more sensible. And you have to use the present tense in the subordinate clause since the main clause has the future tense. (no. 3, $\mathrm{f}, \mathrm{FH}$ )

(36) By going over grammar and grammatical rules together in the English class. (no. 3, f, FH)

The responses of this senior high school student prove that she had acquired an understanding of how the whole is constructed and how it functions, in other words, the student comprehended. It would appear that this student can explain association between issues better than earlier and use what has been learned in a mindful way in new situations (i.e. effectiveness of instruction), issues previously examined by other researchers, including Helmstad (1999, pp. 134-161), James (1998, 1999), Donato (2000), (Dufva (2000) and Luchtenberg (2014). Hautamäki et al. (2000, p. 17) call this phenomenon learning to learn.

The statistical analysis showed a significant difference between the responses of the Finnish and the German senior high school students $(\mathrm{n}=400)$, and the Finnish and the German student teachers $(\mathrm{n}=236)$ to the first and the second questions. The difference for the first question was $(\chi 2(4)=141,930 ; p=0,000)$ and for the second question $(\chi 2(4)=$ $57,044 ; p=0,000)$ in favor of the Finnish and German senior high school students. It would seem that the Finnish and German senior high school students were more aware of English grammar than the Finnish and German teacher students. They were also more aware of how they had been taught grammar or of how they should be taught than the Finnish and German teacher students were of teaching grammar.

The percentages of the responses to the first question (see Table 1) given by the German senior high school students and by the student teachers between the different categories were larger than those of the Finnish senior high school 
students and student teachers. An additional challenge to the analysis was brought out by the fact that responses by single Finnish and German senior high school students and student teachers to the second question did not also automatically fall into the same category in which we had placed their responses to the first question (see Tables 1 and 2). The long passage of time since the high school days of the student teachers may be a factor here, as well as the fact that English grammar is not discussed on the basis of pedagogical grammar in the universities. The student teachers had not internalized the ways grammar should be taught in the context of teaching lessons at school and they lacked school experience. Based on the percentages it is difficult to determine which participants, the senior high school students or the student teachers, comprehend English grammar better, or whether there is any difference in the way they thought English grammar should be taught in the school context.

The gender of the study participants had no statistical link to the responses they gave. This is consistent with the view of Ellis (1994, pp. 202-204) concerning the connection of gender with learning a foreign language. According to Ellis, the possible differences regarding learning a language relate to a person's age, the ethnic background, and above all, the social class. Any proven biological or specifically neurological language acquisition related to sex differences adjust by the age of seventeen, and therefore cannot be taken into consideration in this study (Böttger, 2016, p. 94). Our study participants formed a homogenous group.

It became evident from the responses of some participants that during a teaching session, form and content of language should be discussed through social interaction with negotiation of meaning (see Donato, 2000; Dufva, 2000; Shulman, 1986; Bachman, p. 682; Andrews, 2001). Language is difficult to understand as a system without grammar as defined by Halliday (1985, p. xxxv). This matter showed up, for instance, in the following explicit response of a German senior high school student:

(37) In my opinion, this grammatical issue in question 1 should be dealt with through more frequent classroom discussions. (no. 322, m, GH)

However, our study showed that the knowledge of grammar of the Finnish and German senior high school students and of the student teachers of both countries is lacking. Based on intuitive or unclear linguistic awareness, senior high school students experienced difficulty in explaining how they have been taught grammar or how it should be taught. Correspondingly, the student teachers experienced difficulty in explaining how they would structure their instruction. We will illustrate this issue by providing the example of responses $(38,39)$ to the first and the second questions by a German student teacher. The responses illustrate his unclear awareness of English grammar and of how grammar should be taught.

(38) A, because the person expresses the sentence. (no. 564, m, GS)

(39) Grammar should not be over-emphasized, as the same message is transferred in both sentences, even if shortened. (no. 564, m, GS)

It became also evident from the responses of some senior high school students and student teachers (for example responses 1 and 4), that their knowledge of grammar was linked to metalinguistic awareness (see Andrews, 1999; Dufva, 2000; Luchtenberg, 2014) and to the understanding of grammar as an insight (see Helmstad, 1999).

Language awareness in our time is 'eine heiße Kartoffel', a hot potato. It is challenging for those who organize education, and it has been taken into account in the Finnish (FNBE, 2015) as well in the German senior high school curricula (ISB, 2004; TMBJS, 2011). Generalizations cannot be made based on the qualitative and the quantitative analysis of the responses of the Finnish and German senior high school students and student teachers to our questions in this study. They can, however, be considered to provide some direction. Language awareness and increasing it by teaching remains a challenge for teachers of foreign languages, because it refers to the learners' reflection on the language code and is mainly a highly cognitive and also an individual process. Our research project is about how we are meeting this challenge. Whilst we were writing the article, we deliberated on how Finnish and German senior high school students studying English as a foreign language and student teachers (EFL) teaching English comprehend English grammar and how it has been taught or should be taught, in other words, the effectiveness of instruction.

\section{References}

Aaltonen, O. (2009). Puhekyvyn olemus, merkitys ja kehitys. In O. Aaltonen, R. Aulanko, A. Iivonen, A. Klippi \& M. Vainio (Eds.), Puhuva ihminen: puhetieteiden perusteet (pp. 10-18). Helsinki: Otava.

Andrews, S. J. (1999). Why do L2 teachers need to 'Know About Language' Teacher metalinguistic awareness and input for learning. Language and Education, 13(3), 161-77. https://doi.org/10.1080/09500789908666766 
Andrews, S. J. (2001). The language awareness of the L2 teacher: its impact upon pedagogical practice. Language Awareness, 10(2, 3), 75-90. https://doi.org/10.1080/09658410108667027

Bachman, L. F. (1991). What does language testing have to offer? TESOL Quarterly, 25(4), 671-704. https://doi.org/10.2307/3587082

Böttger, H. (2016). Neurodidaktik des frühen Sprachenlernens: Wo die Sprache zuhause ist. Stuttgart: utb/Verlag Julius Klinkhardt.

CEF, (2001). Common European Framework of Reference for Languages: learning, teaching, assessment. Cambridge: Cambridge University Press.

Denzin, N. K., \& Y. S. Lincoln (2005). Introduction: the discipline and qualitative research. In N. K. Denzin \& Y. S. Lincoln (Eds.), The Sage handbook of qualitative research (pp. 1-32). Thousand Oaks, CA: Sage Publication.

Dirven, R. (1990). Pedagogical grammar. Language Teaching, 23(1), 1-18. https://doi.org/10.1017/S0261444800005498

Donato, R. (2000). Sociocultural contribution to understanding the foreign and second language classroom. In J. Lantolf (Ed.), Sociocultural theory and second language learning (pp. 26-27). Oxford: Oxford University Press.

Dufva, H. (2000). Puheen ja kirjoituksen maailmat: eräs näkökulma lukemaan oppimiseen. In P. Kalaja \& L. Nieminen (Eds.), Kielikoulussa - kieli koulussa (pp. 71-93). AFinLAn vuosikirja 2000. Jyväskylä: Suomen soveltavan kielitieteen yhdistys.

Ellis, R. (1994). The study of second language acquisition. Oxford: Oxford University Press.

FNBE, (2015). Finnish National Bord of Education. National core curriculum for general upper secondary schools. Helsinki: Opetushallitus.

Gass, S. M., \& Selinker, L. (2001). Second language acquisition. An introductory course. Mahwah, NJ: Lawrence Erlbaum.

Halliday, M. A. K. (1985). An introduction to functional grammar. London: Edward Arnold.

Hautamäki, J., Airinen, P., Hautamäki, A., Kauppinen, S., Lindholm, B., Niemivirta, M., \& Scheinin, P. (2000). Oppimaan oppimisen arviointi. In J. Hautamäki, P. Airinen, A. Hautamäki, M. Ikonen-Varila, S. Kauppinen, B. Lindholm, M. Niemivirta, P. Rantanen, M. Ruuth \& P. Scheinin (Eds.), Oppimaan oppiminen yläasteella. Oppimistulosten arviointi 7 (pp. 1-31). Opetushallitus. Helsinki: Yliopistopaino.

Helmstad, G. (1999). Understandings of understanding. An inquiry concerning experiential conditions for development learning. Göteborg Studies in Educational Sciences 134. Göteborg: Acta Universitatis Gothoburgensis.

ISB, (2004). Staatsinstitut für Schulqualität und Bildungsforschung. Lehrplan für das Gymnasium in Bayern. München. Retrieved December $\quad 11, \quad 2017, \quad$ from http://www.isb-gym8-lehrplan.de/contentserv/3.1.neu/g8.de/id_26214.html

James, C. (1998). Errors in language learning and use. Exploring error analysis. Essex: Longman.

James, C. (1999). Language awareness: implications for the language curriculum. Language, Culture and Curriculum, 12(1), 94-115. https://dol.org/10.1080/07908319908666571

Karlsson, F. (2000). Yleinen kielitiede. Helsinki: Yliopistopaino.

Knapp, A. (2010). Sprachaufmerksamkeit, Sprachbewusstheit. In H. Barkowski \& H.-J. Krumm (Eds.), Fachlexikon Deutsch als Fremd- und Zweitsprache (pp. 296-297). Tübingen und Basel: A. Francke Verlag.

Koivisto, M. (2006). Tietoisuus ja tarkkaavaisuus. In H. Hämäläinen, M. Laine, O. Aaltonen \& A. Revonsuo (Eds.), Mieli ja aivot. Kognitiivisen neurotieteen oppikirja (pp. 286-292). Kognitiivisen neurotieteen tutkimuskeskus. Turku: Turun yliopisto.

Kotimaisten kielten keskus. (2017) Kielitoimiston sanakirja. Retrieved October 10, 2017 from https://www.kielitoimistonsanakirja.fi/

Krashen, S. (1994). The Input Hypothesis and Its Rivals. In N. Ellis (Ed.), Implicit and Explicit Learning of Languages (pp. 45-77). London: Academic Press.

Luchtenberg, S. (2014). Language Awareness. In: B. Ahrenholz \& I. Oomen-Welke (Eds.), Deutsch als Zweitsprache (pp. 107-117). Baltmannsweiler: Schneider-Verlag Hohengehren. 
Mattila, I., \& Mattila, M. (1984). Englannin kielioppi. Helsinki: Otava.

Metsämuuronen, J. (2003). Tutkimuksen tekemisen perusteet ihmistieteissä. Jyväskylä: Gummerus.

Nevala, S. (2014). Uuden tiedon luominen yhdistyksessä-Neljä vaihetta nirvanaan. Retrieved October 15, 2018, from https://blog.avoine.fi/kirjoitukset/uuden-tiedon-luominen-yhdistyksessa-nelja-vaihetta-nirvanaan/

Nicholas, H. (1991). Language awareness and second language development. In C. James \& P. Garrett (Eds.), Language awareness in the classroom (pp. 78-95). London: Longman.

Odlin, T. (1994). Introduction. In T. Odlin (Ed.), Perspectives on pedagogical grammar (pp. 1-22). Cambridge: Cambridge University Press. https://doi.org/10.1017/CBO9781139524605.003

Penttinen, E., \& Behning, J. (2017). Lukiolaisten ja opettajaopiskelijoiden tietoisuus englannin kieliopista ja sen pedagogiikasta-vertailussa Suomi ja Saksa. In S. Latomaa, E. Luukka \& N. Lilja (Eds.), Kielitietoisuus eriarvoistuvassa yhteiskunnassa (pp. 239-256). AFinLAn vuosikirja 2017. Jyväskylä: Suomen soveltavan kielitieteen yhdistys.

Penttinen, E. (2005). Kielioppi virheiden varjossa. Kielitiedon merkitys lukion saksan kieliopin Opetuksessa. Jyväskylä Studies in Humanities 43. Jyväskylä: Jyväskylän yliopisto.

Polanyi, M. (1966/1983). The tacit dimension. Gloucester, MASS.: Peter Smith/Doubleday \& Company.

Shulman, L. S. (1986). Those who understand: knowledge growth in teaching. Educational Researcher, 15(2), 4-14. https://doi.org/10.3102/0013189X015002004

Spinney, L. (1999). Älä rypistä. Luota intuition. Tiede 2000, 19(1), 49-52. https://doi.org/10.1111/j.1741-6612.2000.tb00143.x

Stern, H. H. (1992). Issues and options in English language teaching. Oxford: Oxford University Press.

Suomi Sanakirja. (2017). Epäselvä. Retrieved April 4, 2017, from https://www.synonyymit.fi/epäselvä

Syrjälä, L. (1994). Tapaustutkimus opettajan ja tutkijan työvälineenä. In L. Syrjälä, S. Ahonen, E. Syrjäläinen \& S. Saari (Eds.), Laadullisen tutkimuksen työtapoja (pp. 9-24). Helsinki: Kirjayhtymä.

TMBJS. (2011). Thüringer Ministerium für Bildung, Jugend und Sport. Lehrplan für den Erwerb der allgemeinen Hochschulreife. $\quad$ Erfurt. $\quad$ Retrieved April 14, 2017, from https://www.schulportal-thueringen.de/media/detail?tspi=1395

Tomlin, R. S. (1994). Functional grammars, pedagogical grammars, and communicative language teaching. In T. Odlin (Ed.), Perspectives on pedagogical grammar (pp. 140-178). Cambridge: Cambridge University Press. https://doi.org/10.1017/CBO9781139524605.009

Verspoor, M., \& H. Behrens. (2011). Dynamic systems theory and a usage-based approach to second language development. In M. Verspoor, K. de Bot \& W. Lowie (Eds.), A dynamic approach to second language development. Methods and techniques (pp. 25-38). Amsterdam: John Benjamins. https://doi.org/10.1075/11lt.29 